UDK 528.541

\title{
PRECIZINIO NIVELIAVIMO SKAITMENINIAIS NIVELYRAIS Wild NA3003 METODIKOS TOBULINIMAS
}

\author{
Boleslovas Krikštaponis, Eglė Tumelienė, Donatas Rekus
}

Geodezijos ir kadastro katedra, Vilniaus Gedimino technikos universitetas, Sauletekio al. 11, LT-10223 Vilnius-40, Lietuva, el.paštas: gi@ap.vtu.lt

\author{
Iteikta 200506 15, priimta 20050629
}

\begin{abstract}
Santrauka. Skaitmeniniais nivelyrais Wild NA3003 precizinis niveliavimas atliekamas vienintele darbo stotyje numatyta seka BFFB (angl. backsight, foresight, foresight, backsight). Pagrindinai dèl šios priežasties gaunama nemaža teigiama dvipusio niveliavimo būdu nustatytu aukščiu skirtumų nesutapimų sankaupa, viršijanti leistinają. Eksperimentiniai matavimai patvirtina, kad taikant simetriškają atskaičiavimų seką stotyse, aukščių skirtumu nesutapimas labai sumažèja. Nesant galimybès programiškai pakeisti skaitmeniniuose nivelyruose numatytos matavimų sekos, pasiūlyta taikyti simetriškają atskaičiavimų seką. Ją taikant matavimų rezultatus būtina fiksuoti niveliavimo žurnale ir lauke apskaičiuoti tikrąsias aukščių skirtumų sumas. Be netinkamos matavimų sekos, matavimų skaitmeniniais nivelyrais rezultatams itakos turi specifinės atskaičiavimų kodinių matuokliu galuose, matuoklių apšviestumo, vertikaliujų nivelyro ir matuoklių poslinkių paklaidos.
\end{abstract}

Raktažodžiai: skaitmeninis nivelyras, kodinè matuoklè, dvipusis precizinis niveliavimas, simetriškoji atskaičiavimuc seka.

\section{Ivadas}

Didelè pažanga niveliavimo technologijoje pasiekta išradus naujus prietaisus - skaitmeninius nivelyrus [1-4]. Jie sukurti 1990 m. Šveicarijoje, o vèliau ir Vokietijoje bei Japonijoje. Skaitmeninių nivelyrų veikimo principas pagristas kodinių matuoklių vaizdo skaitmeniniu apdorojimu. Be akivaizdžių privalumų (automatinis atskaitų kodinèse matuoklèse atskaičiavimas, registravimas ir saugojimas prietaiso atminties bloke, matavimu niveliavimo stotyje kontrolè pagal pasirinktas tolerancijas, pirminis rezultatu apdorojimas ir t. t.), skaitmeniniai nivelyrai turi trūkumų, kurie pastebimi tik atliekant daug gamybinių matavimų. Todèl būtini konkrečių modelių skaitmeninių nivelyrų ir kodinių matuokliu tikslumo, techninių, geometrinių ir metrologiniu parametrų stabilumo tyrimai. Preciziniam niveliavimui taikant skaitmeninius nivelyrus, reikia ivertinti papildomai veikiančius specifinius paklaidu šaltinius, dèl kurių keičiasi niveliavimo metodika.

Sudarant Lietuvos geodezini vertikaluji tinklą aukščių skirtumai tarp punktų nustatomi skaitmeniniais nivelyrais Wild NA3003 ir precizinèmis kodinemis matuoklèmis Wild GPCL3 su invarinèmis juostelèmis. Skaitmeniniai nivelyrai ir kodinès matuoklès tyrinèta užsienio šalyse [2, 4] ir Lietuvoje [5-8]. Atlikus detalius gamybinius ir laboratorinius tyrimus nustatyta, kad matavimų tikslumą lemiančios skaitmeninių nivelyrų ir matuokliu prietaiso paklaidos nèra didesnès nei analoginių optinių nivelyrų [5, 8]. Tačiau skaitmeninių nivelyru konstruktorių idiegta matavimu seka niveliavimo stotyse yra kitokia, nei daugelio šaliu niveliavimo instrukcijose bei normose reglamentuojama dirbant su analoginiais optiniais nivelyrais. Dèl šios priežasties padidèja sisteminguju paklaidų ittaka, galop pasireiškianti nemaža teigiama aukščių skirtumų, gautų atliekant dvipusi (tiesiogini ir atgalini) niveliavimą, nesutapimų sankaupa ilgose niveliacijos linijose. Metodika šio pobūdžio matavimų paklaidoms sumažinti pateikta darbe [9].

Šio darbo tikslas - remiantis skaitmeniniais nivelyrais atliktų gamybinių matavimų rezultatais, ištirti sistemingujų paklaidų ittaką ir parengti metodiką, kuri leistų sumažinti dvipusių ejjimų aukščių skirtumų nesutapimų kaupimąsi.

\section{Aukščių skirtumų matavimų metodikos tobulinimas}

Lietuvos geodezinio vertikaliojo tinklo punktų aukščiu skirtumai nustatomi atliekant precizini niveliavimą dviem skaitmeniniu nivelyrų Wild NA3003 bei precizinių kodinių invarinių matuoklių GPCL3 komplektais pagal reglamento [10] reikalavimus. Skaitmeninio nivelyro NA3003 veikimo principas pagristas $2^{\circ}$ kampu matomo matuoklès kodinio vaizdo skaitmeniniu apdorojimu. Kodinių matuoklių rodmenys automatiškai ịrašomi i duomenu kaupikli (REC moduli); jie taip pat parodomi displejuje. Tuo sutrumpinama matavimų lauke trukmè, padidèja niveliavimo tikslumas, nes nereikia niveliuotojui atskaičiuoti matuoklèse, panaikinamos atskaičiavimų iš matuoklių ir rezultatų užrašymo apsirikimo galimybès. Darbo efektyvumas labai priklauso nuo niveliavimo stotyje trukmès, kuri yra susijusi su optimalaus atskaičiavimų kodinèse matuoklèse skaičiaus parinkimu. Dirbant skaitmeniniais nivelyrais NA3003, galima taikyti norimą (1-99) atskaičiavimų 
matuoklëje skaičių. Eksperimentiniais tyrimais [7] irodyta, kad kodinių atskaitų tikslumas nèra tiesiogiai susijęs su atskaičiavimu skaičiumi, ir nėra tikslinga taikyti didesni nei ,5“ atskaičiavimų skaičių. Skaitmeninio nivelyro programine iranga pagal parinktas tikslumo tolerancijas kontroliuoja matavimų procesą. Dviejų aukščių skirtumų nesutapimas stotyje $S$ palyginamas su nivelyre ivesta tolerancija Stat Tol (pvz., $0,2 \mathrm{~mm}$ ) (čia ir toliau pateikiami nivelyro programineje irangoje vartojami žymenys), ir kai šios sąlygos laikomasi, displèjuje matoma aukščiu skirtumų vidurkio vertè. Atstumų iki matuoklių skirtumų sankaupa kontroliuojama tolerancija Dist Tol (pvz., 1,0 m). Baigus niveliavimą stotyje galima sužinoti aukščių skirtumą, niveliuoto taško altitudę GrHt (aukščiu skirtumų sumą, jei laikoma, kad pradinio reperio altitude $G r H t=0)$, atstumų iki matuoklių skirtumų sankaupą, ejjimo ilgi, aukščiu skirtumų nesutapimų stotyse sankaupą. Skaitmeninis nivelyras pataiso kodinių matuoklių atskaitas kolimacijos paklaidos (kampo i) pataisomis. Kolimacijos paklaidos verte būna nustatyta ir îvesta $\mathfrak{i}$ prietaiso atminti - tai absoliučioji kolimacijos paklaida absColl. Šių nivelyrų kolimacijos paklaida gali būti nustatoma naudojantis priežiūros programa $C H E C K \&$ ADJUST ir atliekant dvigubą $45-50 \mathrm{~m}$ ilgio vietovès atkarpos niveliavimą. Tikrinant nustatoma kintančioji kolimacijos paklaidos dalis CollDif. Atlikti skaitmeninių nivelyru NA3003 CollDif duomenu kaitos per dieną tyrimai irodo, kad CollDif labiausiai priklauso nuo oro temperatūros [6]. Naujoji absoliučioji kolimacijos paklaida yra lygi senosios absoliučiosios ir naujai nustatytos kintančiosios paklaidų sumai. Absoliučioji kolimacijos paklaida absColl, atsižvelgiant it CollDif reikšmę, gali būti îvesta nauja arba palikta senoji. Niveliuojant Lietuvos valstybinio geodezinio vertikaliojo pirmosios klasès tinklo punktus, svarbiausioji skaitmeninių nivelyrų NA3003 sąlyga paprastai tikrinama esant vidutinėms meteorologinėms sąlygoms. Kuo nivelyro tikrinimo metu meteorologinès sąlygos panašesnès i visos ekspedicijos vidutines sąlygas, tuo CollDif esti mažesnè. Skaitmeninis nivelyras pataiso atskaitas tik dèl absColl. Esant didesniems oro temperatūros šuoliams kolimacijos paklaidą tikslinga nustatyti iš naujo. Matavimų rezultatai programiškai taisomi pataisa dèl Žemès kreivumo.

Svarbus skaitmeninių nivelyrų NA3003 trūkumas yra vienintelè operacineje sistemoje numatyta precizinio niveliavimo veiksmų seka stotyje - atskaičiavimai atgalinèje, priekinejje, priekinejje ir atgalinèje matuoklèse BFFB. 1998-1999 m. Lietuvos geodezinio vertikaliojo pirmosios klasès tinklo matavimu metu isitikinta, kad dvipusio niveliavimo aukščiu skirtumų nesutapimai $d$ gaunami daugiausia teigiami, turi tendenciją kauptis vidutiniškai po $0,3-0,4 \mathrm{~mm} / \mathrm{km}$. Todèl aukščiu skirtumų nesutapimų $d$ sankaupa ilgose niveliacijos linijose iki 3 kartų viršija leistinają sankaupą [10] - 2,0 mm $\sqrt{L}$, čia $L$ - linijos ilgis, km (1 pav.). Tai gali būti dèl kelių priežasčių: kampo CollDif kaitos, kompensatoriaus liekamosios paklaidos, matuoklių ir nivelyro vertikaliuju poslinkių ir t. t. Šių paklaidų ịtaką sumažintų simetriškoji matavimų seka dviejose niveliavimo stotyse - BFFB, $F B B F$.

Atliktas niveliavimo skaitmeniniais nivelyrais NA3003 metodikos itakos rezultatams eksperimentas. Buvo parinkta 0,94 km ilgio niveliavimo trasa, jungianti keturis gruntiniais ženklais paženklintus punktus. Nužymėta 18 niveliavimo stočiuc, išlaikant vizavimo spindulių vienodumą $0,2 \mathrm{~m}$ tikslumu. Didžiausias atstumas iki matuoklių buvo $32 \mathrm{~m}$, o vidutinis $-26 \mathrm{~m}$. Siekiant eliminuoti galimus vertikaliuosius matuokliu poslinkius, ryšio taškuose metaliniai kuolai buvo sukalti iš vakaro. Kitą dieną du skaitmeniniai nivelyrai NA3003 bei kodinių matuoklių komplektas, kad igautu aplinkos temperatūrą, i lauką išnešti $40 \mathrm{~min}$. prieš niveliavimo pradžią. Trasa niveliuota atliekant dvipusi niveliavimą, t. y. tiesiogini ir atgalini ejjimus. Kiekvienoje stotyje niveliuota vienu metu abiem nivelyrais, atskaičiuojant atskaitas dviejose matuoklèse. Nivelyru Nr. 92432 dvipusis niveliavimas visose stotyse atliktas pagal numatytają niveliavimo seką $B F F B$ (atskaičiavimai atgalinèje, priekinëje, priekinejje ir atgalinèje matuoklèse).

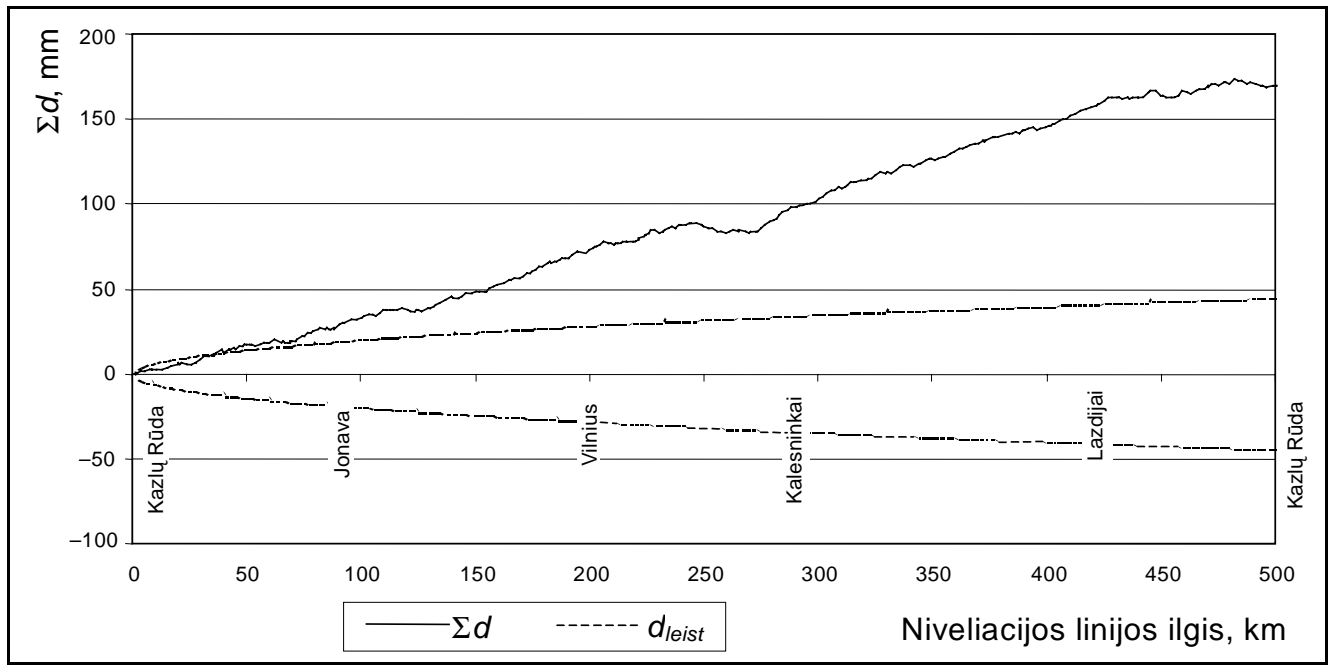

1 pav. Aukščių skirtumų nesutapimų sankaupa penktajame poligone

Fig 1. Accumulation of heights differences incoincidences in the fifth polygon 
Nivelyru Nr. 92426 niveliuota pagal simetriškają schemą, tiesioginio niveliavimo nelyginèse stotyse taikant atskaičiavimų seką $B F F B$, o lyginèse stotyse seką $F B B F$ (atskaičiavimai priekinejje, atgalinèje, atgalinèje ir priekinèje matuoklèse). Atliekant atgalini ejimą matuoklès sukeistos vietomis ir dirbant nivelyru Nr. 92426 nelyginėse stotyse taikyta atskaičiavimų seka $F B B F$, o lyginèse stotyse - seka $B F F B$, t. y. visose dvipusio niveliavimo stotyse niveliuoti pradèta nuo pirmosios matuoklès. Kadangi skaitmeninio nivelyro procesorius visais atvejais skaičiuoja pagal $B F F B$ matavimu seką, nivelyru Nr. 92426 tiesioginio ejjimo lyginèse stotyse ir atgalinio ejjimo nelyginèse stotyse gauti aukščių skirtumai yra priešingu ženklų. Apskaičiuoti atskirai kiekvienu nivelyru išmatuotu aukščiu skirtumų nesutapimai $d$, sankaupos $\sum d$ ir leistinieji nesutapimai $d_{\text {leist }}$ nuo èjimo pradžios. Taikytos formulès:

$$
\begin{aligned}
& d=h_{i j}+h_{j i}, \\
& d_{\text {leist }}=0,5 \mathrm{~mm} \sqrt{n},
\end{aligned}
$$

čia $n$ - stočių skaičius.

Matavimu ir skaičiavimuz rezultatai pateikti 2 paveiksle.

Iš 2 pav. matyti sisteminè $d_{1}$ sankaupa nivelyro NA3003 Nr. 92432, kuriuo visą laiką matuota pagal $B F F B$ metodiką. Nivelyru Nr. 92426, matavusiu pagal $B F F B, F B B F$ metodika, gauta $d_{2}$ sankaupa yra artima nuliui. Eksperimento rezultatai patvirtina, $\mathrm{kad}$ skaitmeniniu nivelyru Wild NA3003 niveliuojant pagal simetriškają atskaičiavimų stotyse seką $(B F F B, F B B F, \ldots)$ gaunama mažesnè dvipusio niveliacijos èjimo aukščiu skirtumų nesutapimų sankaupa.

Išvada - niveliuojant skaitmeniniais nivelyrais NA3003 ir norint gauti patikimus matavimu rezultatus, būtina lyginèse tiesioginio ejjimo stotyse arba visose niveliavimo stotyse matavimus pradeti nuo tos pačios (pirmosios) matuoklès. Taikant tokią metodiką ir norint lauke apskaičiuoti niveliacijos ejjimo nesąryši, reikia pildyti niveliacijos žurnalą, užrašyti aukščių skirtumu reikšmes, o baigus niveliacijos ejjimą, lauke apskaičiuoti lyginių stočių aukščių skirtumų sumas, tikrąsias tiesioginio ir atgalinio ejjimų aukščių skirtumų sumas bei aukščių skirtumų nesutapimą $d$. Be to, nelieka atstumų iki matuoklių skirtumų kontrolès. Atstumų iki matuoklių skirtumų sankaupa galima sužinoti tik perrašius niveliavimo duomenis $\mathfrak{i}$ kompiuteri ir atlikus papildomus skaičiavimus. Tikroji niveliacijos ejjimo aukščiu skirtumų suma $\sum h$ gaunama iš formulès

$$
\sum h=\sum h_{n}-\sum h_{l},
$$

čia $\sum h_{n}$ ir $\sum h_{l}-$ atitinkamai nelyginių ir lyginių stočių aukščiu skirtumų sumos. Skaitmeniniu nivelyru NA3003 nustatytoji aukščių skirtumu suma $\mathrm{GrHt}$ gaunama iš išraiškos

$$
G r H t=\sum h_{n}+\sum h_{l} .
$$

Iš (3) ir (4) formulių skirtumo randama tikroji aukščių skirtumų suma:

$$
\sum h=G r H t-2 \sum h_{l} .
$$

Dabar vertikaliojo tinklo punktu precizinis skaitmeninis niveliavimas atliekamas taip. Antrojoje ir kitose lyginèse tiesioginio èjimo bei nelyginèse atgalinio ejjimo stotyse matavimai pradedami nuo pirmosios matuoklès (t. y. nors displejjuje rodoma $B K 1$, matuojama FRl ir t. t.). Dèl šios priežasties gaunamas priešingo ženklo aukščiu skirtumas HDif, o atstumu iki matuoklių nevienodumo sankaupa $d$ yra neteisinga. Lyginiu stočių HDif rašomas i niveliavimo žurnalo (3 pav.) patamsintaji langeli (stočių HDif nuskaitomas ypač atidžiai, nes jų reikšmès naudojamos lauke skaičiuojant niveliacijos ejjimu nesąryšius). Baigus matavimus paskutinèje tiesioginio ejimo stotyje, paspaudus atitinkamus meniu mygtukus nuskaitoma galinio reperio altitude $\mathrm{GrHt}$ (išmatuotų aukščių skirtumų vidurkių suma) ir ejjimo ilgis $\sum D$. Jie i̇rašomi ì niveliavimo žurnalą. Pradedant atgalini ejjimą, ant reperio statoma antroji matuoklè (t. y.

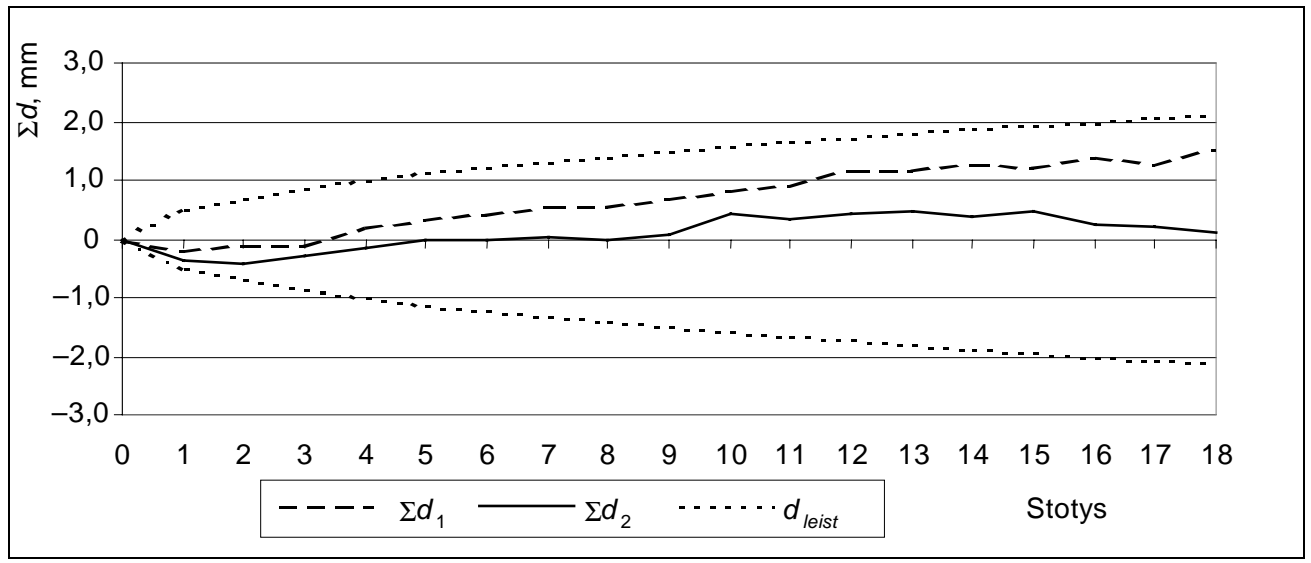

2 pav. Eksperimentinių matavimų aukščių skirtumų nesutapimų sankaupa

Fig 2. Accumulation of heights differences incoincidences of the experimental measurements 
matuoklès keičiamos vietomis). Žurnale atgalinio èjimo aukščiu skirtumu skiltis pildoma nuo apačios. Pravartu palyginti gaunamus tiesioginio ir atgalinio ejjimo aukščiuc skirtumus (jǔ ženklai turi būti skirtingi, priešingai - yra sukeista stebejimų seka). Iš (1) formulès galima apskaičiuoti aukščių skirtumų nesutapimą ir iš (6) formulès - nesutapimų kaupimąsi kiekvienoje atgalinio ejimo stotyje:

$$
\sum d=-d_{1}+d_{2}-d_{3}+d_{4} \cdots
$$

Jei kurio niveliacijos kuolo aukštis pakito, skirsis dvieju gretimų stočių aukščių skirtumai. Jei viso èjimo kuolai išliko stabilūs, gaunamos panašios, bet skirtingu ženklų $G_{r H t}$ ir $G_{t} t_{a}$ reikšmès. Turint tiesioginio ir atgalinio niveliavimo rezultatus, randamos lyginių (patamsintuose langeliuose irašytu) stočių aukščių skirtumų sumos $\sum h_{l}$ ir skaičiuojamos tikrosios aukščių skirtumų sumos $\sum h$. Jos turètų būti beveik vienodos, bet priešingų ženklų. Skaičiuojamas niveliacijos èjimo aukščiu skirtumų nesutapimas (nesąryšis) $d=\sum h_{t}+\sum h_{a}$. Niveliacijos èjimo matavimų rezultatai yra kokybiški, jei $d \leq 2 \mathrm{~mm} \sqrt{L}$, kai $L \geq 1 \mathrm{~km}$, arba $d \leq 0,5 \mathrm{~mm} \sqrt{n}$, kai $L<1 \mathrm{~km}$ (čia $n$ - stočių skaičius), ir galima pradèti kito ejjimo niveliavimą. Niveliacijos žurnale taip pat irašoma ejjimo pradinio ir galinio punktų itvirtinimo pobūdis ir numeriai pagrindine linijos niveliavimo kryptimi, tiesioginio ir atgalinio ejimu niveliavimo data, niveliavimo pradžios ir pabaigos antrosios juostos vasaros laikas $V_{2}$, matuoklių numeriai. Žurnale apibūdinamas debesuotumas, vejjo stiprumas ir trasos gruntas. Niveliavimo žurnalo pavyzdys duotas 3 pav.

Ėjimas nuo sien. rp. 15342 iki grunt. rp. 10285

Tiesiog. èj. 200405 14, pradèta 10:15, baigta 11:25, ant rp. mat. 26600, atgal. èj. 200405 14, pradèta 17:50, baigta 18:45, ant rp. mat. 26605

Debesuotumas vidutinis. Vejjas silpnas. Gruntas žvyras

\begin{tabular}{|c|c|c|c|c|c|c|}
\hline \multirow{2}{*}{$\begin{array}{l}\text { Stoties } \\
\text { Nr. }\end{array}$} & \multirow{2}{*}{$\begin{array}{l}\text { Taško } \\
\text { Nr. }\end{array}$} & \multicolumn{4}{|c|}{ Aukščių skirtumas, m } & \multirow{2}{*}{$\begin{array}{c}d / \Sigma d \\
10^{-2} \mathrm{~mm} \\
\end{array}$} \\
\hline & & \multicolumn{2}{|c|}{ tiesioginis èjimas } & \multicolumn{2}{|c|}{ atgalinis èjimas } & \\
\hline 1 & Rp. 15342 & 0 & 14591 & -0 & 14628 & $-37 /-89$ \\
\hline 2 & 1 & -0 & 84498 & 0 & 84518 & $-20 /-52$ \\
\hline 3 & 2 & 0 & 29686 & -0 & 29723 & $-37 /-32$ \\
\hline 4 & 3 & -0 & 27322 & 0 & 27337 & $-15 / 5$ \\
\hline 5 & 4 & -0 & 11179 & 0 & 11152 & $-27 / 20$ \\
\hline \multirow[b]{2}{*}{7} & 5 & 0 & 22996 & -0 & 23036 & $40 / 47$ \\
\hline & 6 & 0 & 02345 & -0 & 02328 & $17 / 7$ \\
\hline 8 & 7 & 0 & 00133 & -0 & 00167 & $34 /-10$ \\
\hline 9 & 8 & 0 & 02800 & -0 & 02786 & $14 /-44$ \\
\hline 10 & 9 & 0 & 17722 & -0 & 17751 & $29 /-58$ \\
\hline 11 & 10 & 0 & 05786 & -0 & 05819 & $-33 /-87$ \\
\hline 12 & 11 & 0 & 03091 & -0 & 03055 & $-36 /-54$ \\
\hline 13 & 12 & -0 & 05547 & 0 & 05560 & $13 /-18$ \\
\hline 14 & 13 & 0 & 14182 & -0 & 14189 & $7 /-31$ \\
\hline 15 & 14 & -0 & 07482 & 0 & 07447 & $-35 /-38$ \\
\hline 16 & 15 & 0 & 11041 & -0 & 11044 & $3 /-3$ \\
\hline 17 & 16 & -0 & 09811 & 0 & 09802 & $-9 /-6$ \\
\hline 18 & 17 & 1 & 81167 & -1 & 81170 & 3 \\
\hline 19 & Rp. 10285 & & & & & \\
\hline 20 & 19 & & & & & \\
\hline 21 & 20 & & & & & \\
\hline & 21 & & & & & \\
\hline$D=1$ & $\begin{array}{r}G r \\
-2 \sum \\
\end{array}$ & $\begin{array}{l}H t_{t}= \\
h_{l_{t}}=\end{array}$ & $\begin{array}{l}, 59701 \mathrm{~m} \\
-2,77024 \mathrm{~m}\end{array}$ & $\begin{array}{l}G r H t \\
\sum h_{l_{a}}\end{array}$ & $\begin{array}{l}=-1,59880 \mathrm{~m} \\
=2,77114 \mathrm{~m}\end{array}$ & $d_{\text {leist }}= \pm 2,08 \mathrm{~mm}$ \\
\hline
\end{tabular}

3 pav. Precizinio niveliavimo žurnalo pavyzdys

Fig 3. Example of journal of precise levelling 


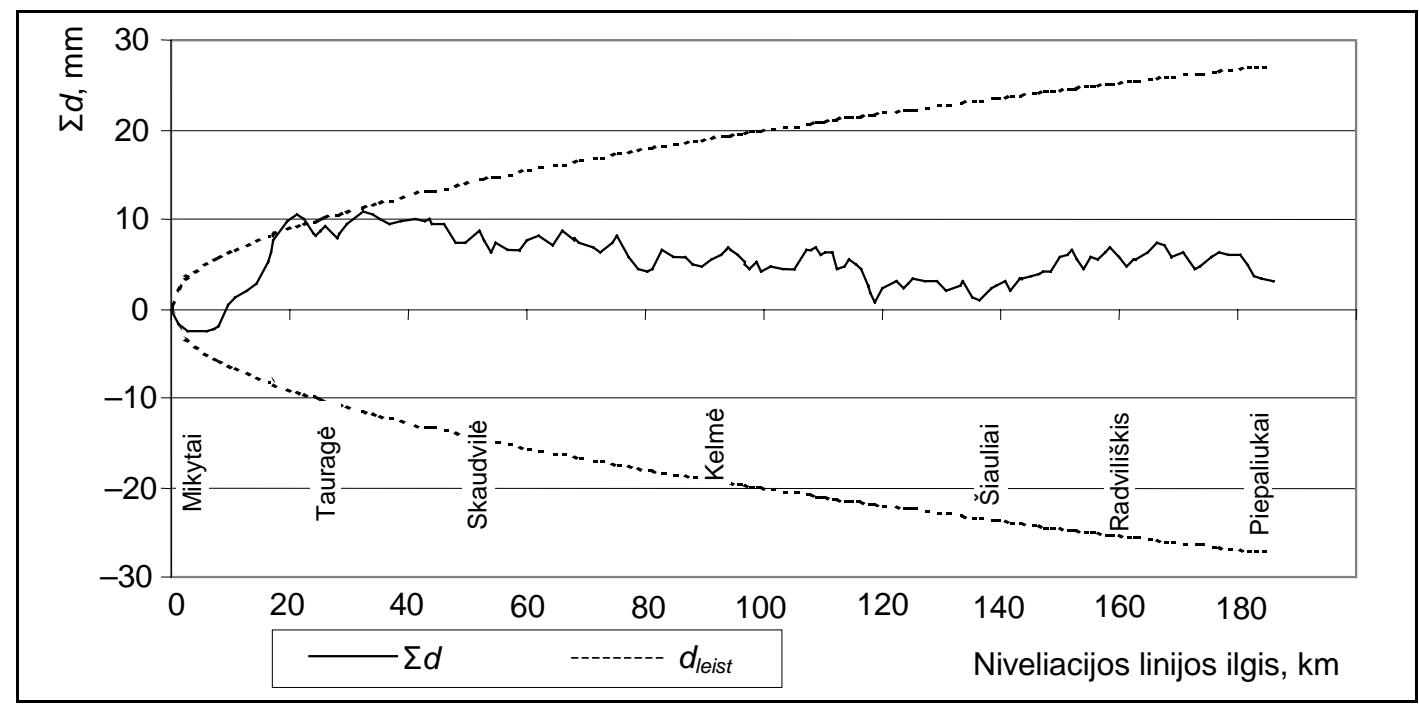

4 pav. 2002 m. gautas aukščių skirtumų nesutapimų sankaupa

Fig 4. Accumulation of heights differences incoincidences of the 2002 year

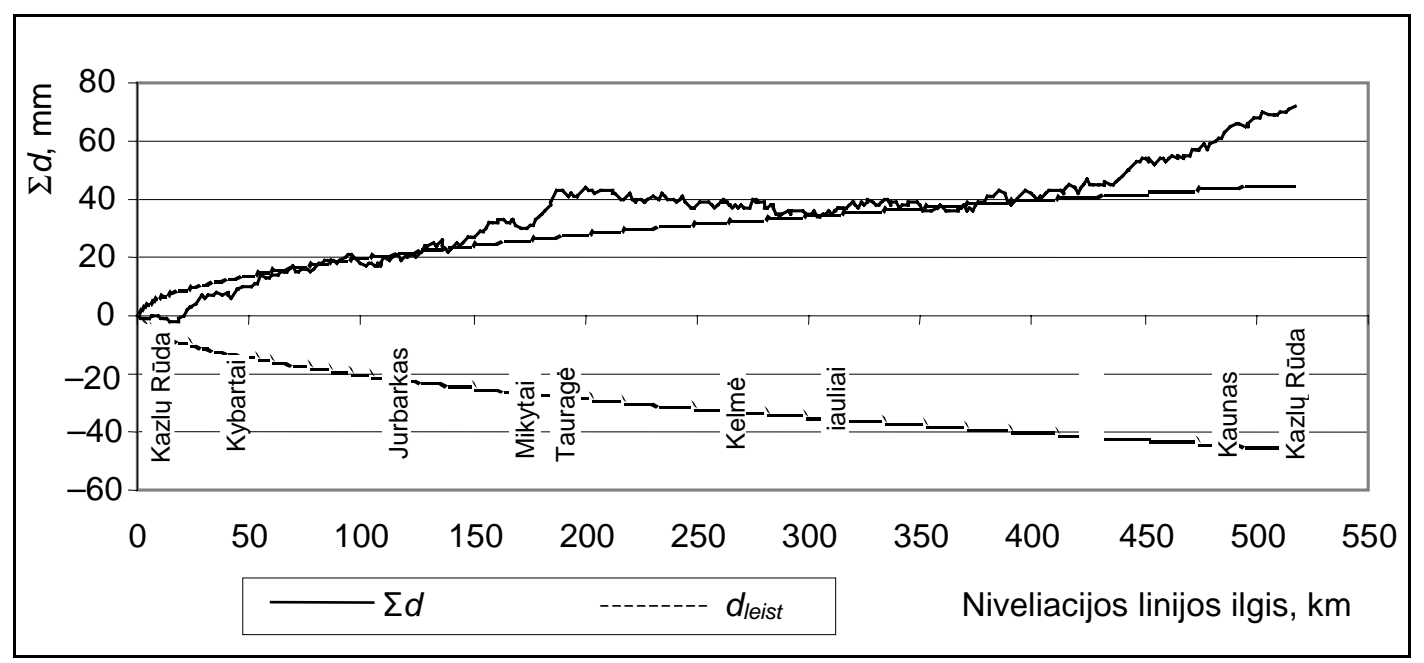

5 pav. Aukščių skirtumų nesutapimų sankaupa antrajame poligone

Fig 5. Accumulation of heights differences incoincidences of the second polygon

2002 m. atlikto vertikaliojo pirmosios klasès tinklo linijos Mikytai - Šiauliai bei linijos Šiauliai - Jonava atkarpos Šiauliai - Piepaliukai precizinio niveliavimo rezultatai nuteikè optimistiškai. 4 pav. parodyta dvipusių ejimų aukščių skirtumų nesutapimų sankaupa iš lauko matavimų duomenų. Niveliavimo rezultatai patvirtina, kad, taikant pasiūlytą niveliavimo metodiką, dvipusių niveliacijos ejjimų aukščių skirtumų nesutapimų sankaupa sumažeja, o niveliacijos linijų sistemingujų paklaidu reikšmès gaunamos maždaug perpus mažesnès.

Tačiau pastaruju metų Lietuvos vertikaliojo tinklo punktų precizinio niveliavimo rezultatai rodo, $\mathrm{kad}$ taikoma metodika negarantuoja visiško sisteminguju paklaidų eliminavimo (5 pav.). Pastebèta, kad sudètingo reljefo vietovèje ypač didelès ịtakos turi specifinès skaitmeninio nivelyro paklaidos dèl kodinių matuoklių nevienodo apšviestumo, judančių šešèlių ant matuoklių ir ypač atskaičiavimų kodinių matuoklių galuose.
Straipsnyje [7] irodyta, kad skaitmeninis nivelyras NA3003 atskaičiuoja atskaitą (matuoja) esant $33 \%$ uždengtai apatinei arba atitinkamai viršutinei stebimo kodinès matuoklès vaizdo daliai. Bet darbe [11] teigiama, kad atskaičiuojant matuokliu galuose atskaitos paklaida gali siekti $0,5 \mathrm{~mm}$. Be to, turi itakos pažeisti matuoklių kodiniai elementai.

\section{Išvados}

1. Skaitmeniniais nivelyrais Wild NA3003 niveliuojant pagal užprogramuotą matavimų seką stotyje $B F F B$, dvipusio niveliavimo aukščiuc skirtumu nesutapimai $d$ gaunami daugiausia teigiami, kaupiasi vidutiniškai po $0,3-0,4 \mathrm{~mm} / \mathrm{km}$ ir niveliacijos linijose iki 3 kartų viršija leistinają aukščiu skirtumų nesutapimų sankaupą.

2. Taikant pasiūlytą darbo stotyje seką labai sumažèja aukščių skirtumų nesutapimų sankaupa. 
3. Niveliuojant skaitmeniniais nivelyrais pastebèta, kad dvigubujų matavimų nesutapimų vertè priklauso nuo aukščių skirtumo dydžio. Matavimų tikslumui įtakos turi specifinès skaitmeninių nivelyrų paklaidos.

\section{Literatūra}

1. Takalo, M. On the digital levelling instruments. Surveying science in Finland, Vol 14, No 1-2, The Finnish society of surveying sciences, Helsinki, 1996, p. 69-85.

2. Becker, J. M.; Andersson, B.; Eriksson, P. O.; Nordquist, A. A new generation of levelling instruments: NA2000 and NA3000. FIG XX. International congress, Melbourne, Australia, 1994, TS509.1/11.

3. Ingensand, H. The evolution of digital levelling techniques - limitations and new solutions. In: Geodesy surveying in the future, the importance of heights, Gävle, Sweden, 15$17^{\text {th }}$ of March, 1999, p. 59-68.

4. Menzel, M. The development of levels during the past 25 years, with special emphasis on the Ni002 optical geodetic level and the DiNi 11 digital level. In: Geodesy surveying in the future, the importance of heights, Gävle, Sweden, 15$17^{\text {th }}$ of March, 1999, p. 85-93.

5. Krikštaponis, B.; Tulevičius, V. Investigation of precise levelling invar rods with bar code scale. Geodesy and Cartography (Geodezija ir kartografija), Vol XXVII, No 1. Vilnius: Technika, 2001, p. 13-19 (in Lithuanian).

6. Krikštaponis, B. Investigation of collimation error of digital levels NA3003. Geodesy and Cartography (Geodezija ir kartografija), Vol XXVII, No 1. Vilnius: Technika, 2001, p. 36-39 (in Lithuanian).

7. Krikštaponis, B. Research on digital level Wild NA3003 reading system peculiarities. Geodesy and Cartography (Geodezija ir kartografija), Vol XXVIII, No 2. Vilnius: Technika, 2002, p. 39-44 (in Lithuanian).

8. Krikštaponis, B. Investigation of observation accuracy of analog and digital levels. Geodesy and Cartography (Geodezija ir kartografija), Vol XXVI, No 2. Vilnius: Technika, 2000, p. 69-72 (in Lithuanian).

9. Zakarevičius, A.; Baškienè, R. Measurements by digital levels: analysis of outliers and possibilities of their reducing. Geodesy and Cartography (Geodezija ir kartografija), Vol XXVIII, No 3. Vilnius: Technika, 2002, p. 83-87 (in Lithuanian).

10. Lithuanian National Geodetic Vertical Network. Technical regulation of requirements. GKTR 2.12.01:2001. National Service of Geodesy and Cartography under the Government of Republic of Lithuania, Vilnius, 2001. 23 p. (in Lithuanian).

11. Woschitz, H.; Brunner, F. K. System calibration of digital levels - experimental results of systematic effects. INGEO 2002. In: $2^{\text {nd }}$ Conference of Engineering Surveying, Bratislava, November 2002, p. 165-172.

Boleslovas KRIKŠTAPONIS. Associate Professor, Doctor. Vilnius Gediminas Technical University, Dept of Geodesy and Cadastre. Saulètekio al. 11, LT-10223 Vilnius-40, Lithuania (Ph +370 5 2744705, Fax +370 5 2744705), e-mail: gi@ap.vtu.lt A graduate of Vilnius Civil Engineering institute (engineer of geodesy, 1974). Doctor (Vilnius Gediminas Technical University, 2002). Training at Moscow Institute of Geodesy, Aerosurveying and Cartography (1976). Author of more than 10 scientific papers.

Research interests: geodetic networks.

Eglé TUMELIENE். Assistant. Vilnius Gediminas Technical University. Dept of Geodesy and Cadastre. Sauletekio al. 11, LT-10223 Vilnius-40, Lithuania $(\mathrm{Ph}+3705$ 2744705, Fax +370 5 2744705), e-mail: petru@ap.vtu.lt

A graduate of Vilnius Gediminas Technical University (VGTU) (MSc, 1995). Master of science studies at Royal Institute of Technology, Stockholm, Sweden in 1999. Author of 3 publications.

Research interests: cadastral surveying, establishing and improving the geodetic networks.

Donatas REKUS. Vilnius Gediminas Technical University. Dept of Geodesy and Cadastre. Sauletekio al. 11, LT-10223 Vilnius-40, Lithuania $(\mathrm{Ph}+3705$ 2744705, Fax +3705 2744705).

A graduate of Vilnius Gediminas Technical University (VGTU) (MSc, 2005).

Research interests: geodetic networks. 